\title{
СПЕЦИФІКА ТА ХАРАКТЕР РОЗСЕЛЕННЯ ПРОМИСЛОВИХ КУЛЬТУР ЕНТОМОФАГІВ ДЛЯ ЗАХИСТУ ЛІСІВ ВІД СОСНОВОГО ШОВКОПРЯДА
}

\author{
Карпович М. С., Дрозда В. Ф.
}

\section{ВСТУП}

Сучасний ареал сосни звичайної зумовлений умовами клімату, рельєфу, іншою рослинністю, а також антропогенним впливом. Рід Pinus L., який є найбільшим у родині Pinaceae Lindl., поширений у лісах помірних і субтропічних зон північної півкулі планети. Він включає близько 100 видів, серед яких найбільшу площу займає сосна звичайна (Pinus sylvestris L.) ${ }^{1}$.

Серед комплексу хвоєгризів, трофічно пов'язаних із сосною звичайною, яка зростає на бідних і піщаних грунтах $2,3,4$, значне місце посідає сосновий шовкопряд Dendrolimus pini L. (Lepidoptera, Lasiocampidae $)^{5}$.

Сосновий шовкопряд $\epsilon$ добре відомим видом шкідників із регулярними спалахами в деяких частинах континентальної Європи ${ }^{6}$, де гусінь спричиняє значне пошкодження соснових лісів ${ }^{7}$. Спалахи фітофага поширені у країнах Центральної та Східної Європи: у Німеччині $^{8}$, Польщі ${ }^{9}$, Литві $^{10}$, Pосіі $^{11}$ та Україні ${ }^{12,13 .}$

\footnotetext{
${ }^{1}$ Гордієнко М.І., Корецький Г.С., Маурер В.М. Лісові культури. Київ : Сільгоспосвіта, 1995. 328 с.

${ }^{2}$ Han, Ruidong, He Zhong, Ge Feng. Factors influencing the population dynamics of pine caterpillars. Entomological Knowledge. 2004. № 41 (6). P. 504-511.

${ }^{3}$ Sukovata, L., Kolk A., Jaroszynska J., Krajewska U., Purzynska A., Isidorov V. Host-tree preferences of the pine moth (Lepidoptera: Lasiocampidae) and pine beauty moth (Lepidoptera: Noctuidae) larvae in relation to needle quality. M.L. McManus and A.M. Liebhold (eds.), Proceedings Ecology, Survey and Management of Forest Insects. USD A Forest Service, Kraków, Poland, 2002.

${ }^{4}$ Szujecki, A. Ecology of forests insects, second ed. Dr W. Junk Publishers and PWN - Polish Scientific Publishers, 1987.

${ }^{5}$ Надзор, учет и прогноз массовых размножений хвое- и листогрызущих насекомых в лесах СССР / ред. А.И. Ильинский, И.В. Тропин. Москва : Лесн. Пром-сть, 1965. 525 с.

${ }^{6}$ Björkman C., Lindelöw A., Eklund K., Kyrk S., Klapwijk M.J., Fedderwitz F. Nordlander G. A rare event - an isolated outbreak of the pine-tree lappet moth (Dendrolimus pini) in the Stockholm archipelago. Entomol Tidskr. 2013. № 134 (1-2). P. 1-9. Uppsala, Sweden.

${ }^{7}$ Malyshev, D.S. Disappearance of mass outbreaks of Dendrolimus pini L. (Lepidoptera, Lasiocampidae). Acta Phytopathologica et Entomologica Hungarica. 1997. № 32 (1-2). P. 217-221.

${ }^{8}$ Le Mellec, A., Michalzik, B. Impact of a pine lappet (Dendrolimus pini) mass outbreak on $\mathrm{C}$ and $\mathrm{N}$ fluxes to the forest floor and soil microbial properties in a Scots pine forest in Germany. Canadian Journal of Forest Research. 2008. № 38. P. 1829-1841.

9 Sierpinska, A. Towards an integrated management of Dendrolimus pini L. McManus, M.M., Liebhold, A.M. (Eds.), Population Dynamics, Impacts, and Integrated Management of Forest Defoliating Insects. GTR NE-247, USDA Forest Service Northeastern Forest Experiment Station, 1998. P. 347-348.

${ }^{10}$ Gedminas, A., Žiogas, A. The influence of Dendrolimus pini L. outbreak on the surrounding standsand forest litter entomofauna. Acta Biologica Universitatis Daugavpiliensis. 2008. № 8. P. $287-296$.
} 
Сосновий шовкопряд також поширений у Центральній Азії та Північній Африці та зазвичай зустрічається на висоті >200 м ( 660 футів) над рівнем моря ${ }^{14}$. Африка: Марокко ${ }^{15}$; Азія: Китай ${ }^{16}$, Казахстан, Республіка Грузія ${ }^{17}$ та Туреччина; $\boldsymbol{E}_{\boldsymbol{в}}$ ропа: Хорватія, Республіка Чехія, Данія, Естонія, Фінляндія, Франція ${ }^{18}$, Німеччина $^{19,}{ }^{20}$, Греція, Угорщина, Італія (включаючи Сицилію), Латвія, Ліхтенштейн, Литва, Люксембург, Македонія, Чорногорія, Нідерланди, Норвегія, Польща ${ }^{21,22,23, ~ П о р т у г а л і я, ~}$ Румунія, Росія, Сербія, Словаччина, Словенія, Іспанія (включаючи Балеарські острови), Швеція ${ }^{24}$, Швейцарія, Україна та Велика Британія.

Спалахи масового розмноження фітофага повторюються в Україні, зокрема у Житомирській, Черкаській ${ }^{25}$, Чернігівській ${ }^{26}$, Київській, Харківській і Херсонській областях ${ }^{27}$. Періодично виникають осередки в лісах зони відчуження ЧАЕС, де в останні роки у хвойних лісах підтримується високий рівень чисельності соснового шовкопряда ${ }^{28}$.

\footnotetext{
${ }^{11}$ Molet, T. CPHST Pest Datasheet for Dendrolimus pini. USDA-APHIS-PPQ-CPHST. 2012. URL: http://download.ceris.purdue.edu/file/3031 (дата звернення: 17.08.2017).

${ }^{12}$ Hardin, J.A., Suazo, A. Control Procedures. In: New pest response guidelines. Dendrolimus pine moths (eds.: A. Hardin, J.A. Suazo). USDA Animal and Plant Health Inspection Service, US Department of Agriculture, USA, 2012. P. 107-122.

${ }^{13}$ Meshkova, V. Foliage browsing insects risk assessment using forest inventory information. IUFRO Working Party 7.03.10 Proc. Workshop, 2006. P. 100-108.

${ }^{14}$ Diaz, J.H. The evolving global epidemiology, syndromic classification, management, and prevention of caterpillar envenoming. American Journal of Tropical Medicine and Hygiene. 2005. № 72. P. 347-357.

${ }^{15}$ Le-Cerf, F. Lepidopteres nauveaux du Moyen Atlas [Morocco (Noctuidae Lasiocampidae]. Bull Mus Nation Hist Nat. 1932. № 4 (5). P. 510-515.

${ }^{16}$ CAB. 2005. Crop Protection Compendium. CAB International. URL: http://www.cabicompendium.org/ срс (дата звернення: 18.10.2006).

${ }^{17}$ Kovalev, B.G., Bolgar T.S., Zubov P.A., Zharkov D.G., Golosova M., Nesterov E.A., Tvaradze M.S. Identification of additional components of the sex pheromone of Dendrolimus pini. Chemistry of Natural Compounds. 1993. № 29. P. 135-136.

18 Malyshev, D.S. Duration of the life cycle of the pine moth Dendrolimus pini L. (Lepidoptera: Lasiocampidae). Entomological Review. 1987. № 67. P. 61-66.

${ }_{19}$ Gäbler, H. Kritische Raupenzahlen des Kiefernspinners. Forstwissenschaftliches Centralblatt. 1949. № 68. P. 254-256.

${ }^{20}$ Varley, G.C. Population changes in German forest pests. The Journal of Animal Ecology. 1949. № 18. P. 117-122.

${ }^{21}$ Leśniak, A. Certain trophic and intrapopulation conditions of the pine moth (Dendrolimus pini L.) outbreaks. Ekologia Polska. 1976. № 24. P. 565-576.

${ }^{22}$ Leśniak, A. Forest stand and site conditions of a pine moth (Dendrolimus pini L.) outbreaks. Ekologia Polska. 1976. № 24. P. 549-563.

${ }^{23}$ Leśniak, A. Climatic and meteorological conditions of the pine moth (Dendrolimus pini L.) outbreaks. Ekologia Polska. 1976. № 24. P. 515-547.

24 Johansson, B.G., Anderbrant, O., Sierpinski A. Multispecies trapping of six pests of Scots pine in Sweden and Poland. Journal of Applied Entomology. 2002. № 126. P. 212-216.

${ }^{25}$ Карпович М.С., Дрозда В.Ф. Роль ентомофагів у популяції соснового шовкопряда (Dendrolimus pini L.) в соснових насадженнях Черкащини. Вісник ХНАУ. Серія "Фітопатологія $і$ ентомологія» 2018. № 1-2. С. 57-62.

26 Чудак В. Інформація про стан лісів Полісся та Поділля України. URL: http://dklg.kmu.gov.ua/ forest/control/uk/publish/article;jsessionid=0496D5C46F8CDF9F264E0C1FC35FC96B.app2?art_id=118307 \&cat_id=81209 (дата звернення: 7.12.2017).

${ }^{27}$ Мєшкова В.Л. Історія і географія масових розмножень комах-хвоєлистогризів. Харків : Майдан, 2002. $244 \mathrm{c}$.

${ }^{28}$ Бунтова О.Г., Бідна С.М., Зленко М.Г., Кучма М.Д., Тютюнник Ю.Г. Чорнобильські ліси: минуле, сучасне, майбутнє. URL: https://inis.iaea.org/collection/NCLCollectionStore/_Public/32/020/32020526.pdf (дата звернення: 12.01.2020).
} 
Дослідження комах-хвоєгризів було розпочато у 2014 р. у трьох лісництвах ДП «Чигиринське ЛГ»: Чорнявському, Трушівському та Чигиринському ${ }^{29}$. Найбільш поширеними були спалахи у 2014 р. в Михайлівському лісництві ДП «Канівське ЛГ»: квартали: 109, 110, 111, 112, 113 (на площі 486 га) та у Трушівському, Чигиринському та Чорнявському лісництвах ДП «Чигиринське ЛГ» ${ }^{30}$. Найбільш заселеними гусеницями (Dendrolimus pini L.) були такі квартали: 1-7, 11-17 і 28-33 Чигиринського лісництва, загальна площа яких 1082 га, а також квартали 30-40, 68-78 Трушівського лісництва, загальна площа 1009 га. Відносна щільність Dendrolimus pini L. становила для насаджень Чигиринського лісництва - від 2 до 13 гусениць на 1 дерево, для насаджень Трушівського лісництва - від 2 до 32 гусениць ${ }^{31}$. Найбільш заселеними гусеницями соснового шовкопряда були квартали 5, 8, 45, 46, 48 Трушівського лісництва ДП «Чигиринське ЛГ» ${ }^{32}$.

Спалахи соснового шовкопряда виявлені весною 2020 р. у трьох лісгоспах: Трушівському лісництві ДП «Чигиринське л/г» (Черкаська обл.) на площі $1300 \mathrm{ra}^{33}$, Шевченківському лісництві ДП «Димирське л/г» на площі 217,5 га ${ }^{34}$ та в Леонівському та Феневицькому лісництвах ДП «Іванківське л/г» на площі 1000 га (Київська область) ${ }^{35}$.

3 метою виявлення стану розвитку гусені соснового шовкопряда у квітні 2020 р. працівниками державної лісової охорони Чигиринського лісгоспу було проведено лісопатологічне обстеження насаджень методом околоту в осередку соснового шовкопряда у Трушівському лісництві. Було встановлено, що щільність шкідника в обстежених насадженнях - від 10 до 90 особин на 1 дерево. За такої щільності ступінь об'їдання хвої може перевищити $50 \%$. Хімічний обробіток лісів Чигиринського лісгоспу здійснювали у 2012, 2013, 2014 рр. Тоді винищувальні заходи проводилися на площах понад 8000 га, і осередки

\footnotetext{
${ }^{29}$ Кукіна О.М. Комахи-хвоєгризи Чигиринського бору. Лісівнищ̧тво і агролісомеліоращія. 2014. Вип. 124. С. 177-184.

30 Дрозда В.Ф., Карпович М.С. Екологічні особливості соснового шовкопряда (Dendrolimus pini L.), його поширення на Черкащині. Лісівництво і агролісомеліорація. Вип. 126. 2015. C. $225-231$.

${ }^{31}$ Перевізник А. В. Обліки популяцій соснового шовкопряда (Dendrolimus pini L.).Науковий пошук молоді для сталого розвитку лісового комплексу та садово-паркового господарства: тези доповідей учасників 73-ої всеукраїнської студентської науково-практичної конференції, 21 березня 2019 р. Київ: НУБІП, 2019. С. 79-80.

32 Перевізник А.В. Обліки популяцій соснового шовкопряда (Dendrolimus pini L.). Науковий пошук молоді для сталого розвитку лісового комплексу та садово-паркового господарства : тези доповідей учасників 73-ої всеукраїнської студентської науково-практичної конференції, 21 березня 2019 р. Київ : НУБІП, 2019. С. 79-80.

${ }^{33}$ Комаха-шкідник нищить насадження сосни на Чигиринщині. URL: https://www.openforest.org.ua/ 140040/ (дата звернення: 24. 06. 2020).

34 Шкідники не знають кордонів. URL: https://dymerlg.com.ua/no_cache/pres-sluzhba/novina/ article/shkidniki-ne-znajut-kordoniv.html (дата звернення: 24.06.2020)

${ }^{35}$ Сосновий шовкопряд Іванківське л/г. URL: https://www.facebook.com/ivankivlis/posts/
} 2304275379865048/ (дата звернення: 25.06.2020) 
поширення шкідників вдалося зупинити ${ }^{36}$. У Трушівському лісництві хімічним методом обробили 500 га лісу від фітофага ${ }^{37}$.

Хімічну обробку лісових насаджень Шевченківського лісництва загальною площею 217,5 га було проведено в таких кварталах: 24, 25, 32, $33,34,35,41$.

Польові дослідження проводились в осередках соснового шовкопряда в ДП «Іванківське л/г» (Леонівського лісництва) з метою визначення щільності заселення дерев сосновим шовкопрядом та визначення стану розвитку гусені. Шляхом околоту модельних дерев віком 75-80 років 3 відносно розвинутими кронами встановлено, що найбільш заселеними були наступні квартали: 50, 51, 60, 61.

Під час проведення обстежень було оцінено загальний санітарний стан насаджень i визначено дефоліацію на час обстеження, яка становила 25-40\%. Відносна щільність соснового шовкопряда становила від 5 до 12 гусениць шовкопряда на 1 дерево ${ }^{38}$.

Мета дослідження - дослідити особливості біології, популяційної екології соснового шовкопряда, трофічну активність гусениць, а відтак, рівень шкідливості фітофага. Ставилося завдання дослідити роль та значення спеціалізованих паразитів видів роду трихограма та теленомуса у динаміці чисельності соснового шовкопряда.

Біотехнологічна складова досліджень передбачала елементи промислового розведення ентомофагів з використанням оригінальних прийомів. Відпрацьовували елементи технології, які передбачали прийоми розселення ентомофагів - норми, строки та кратності.

У завдання досліджень входило: використання загальноприйнятих у галузях ентомології, біотехнології та паразитології методів; збір яйцекладок та гусениць соснового шовкопряда; аналіз зібраного матеріалу; встановлення рівня зараження ентомофагами яєць шовкопряда, визначення основних факторів смертності яєць та гусениць соснового шовкопряда; обгрунтування доцільності та перспективи лабораторного вирощування трихограми та теленомуса для контролю та шкідливості соснового шовкопряда.

\footnotetext{
36 На Чигиринщині сосновий шовкопряд нищить насадження - лісівники проведуть хімічний обробіток, проте лише на частині площ. URL: https://is-ck.gov.ua/?p=22086 (дата звернення: 30.06. 2020).

37500 гектарів лісу у Трушівцях обробили від шкідників. URL: https://suspilne.media/35013-500gektariv-lisu-u-trusivcah-obrobili-vid-skidnikiv/ (дата звернення: 25.06.2020).

${ }^{38}$ Карпович М.С., Дрозда В.Ф. Поширення соснового шовкопряда (Dendrolimus pini L.) в соснових насадженнях України. Збірник наукових матеріалів XLVIII міжнародної науково-практичноі інтернет-конференеціï el-conf.com.иа. м. Тернопіль. 2020. С. 64-68.
} 


\section{1.Біологічні й екологічні особливості соснового шовкопряда 1.1. Біологічні й екологічні особливості фітофага й ентомофагів}

Сосновий шовкопряд (Dendrolimus pini L.) $є$ одним iз найнебезпечніших фітофагів соснових лісів в Україні ${ }^{39}$. Його осередки частіше виникають у чистих соснових насадженнях будь-якого віку (частіше у 20-40-річних), які ослаблені за тих чи інших причин: екологічних - синоптичні аномалії; антропогенних - зрідження деревостанів тощо ${ }^{40}$. На Поліссі за умов сухого та свіжого бору його осередки виникають у культурах II-III віку ${ }^{41}$. Сосновий шовкопряд $\epsilon$ світло-, тепло- і посухостійким видом ${ }^{42}$.

Живиться фітофаг хвоєю сосни звичайної, торішньою хвоєю навесні та хвоєю поточного року влітку ${ }^{43,44,45}$.

За нашими дослідженнями, одна гусениця соснового шовкопряда за період свого розвитку з'їдає в середньому 650-750 хвоїнок, із них 540590 - після зимівлі ${ }^{46}$. Це свідчить про значну трофічну активність гусениць, а відтак і шкодочинність.

Із наукової інформації відомо, що гусениці соснового шовкопряда живляться всіма видами підродини (соснові) Pinoideae: сосною румелійською (P. Peuce Griseb.) ${ }^{47}$, сосною кримською (Pinus nigra ssp. pallasiana), сосною чорною (P. nigra Arnold $)^{48,49}$, сосною гірською (P. mugo Turra. (P. montana Mill.) $)^{50}$, сосною Банксою (P. banksiana Lamb. $)^{51}$, сосною Веймутовою (P. strobus L. $)^{52}, 3$ підродини ялицеві

\footnotetext{
${ }^{39}$ Краснов В.П., Ткачук В.І., Орлов В.В. Довідник із захисту лісу. Київ : Еко-інформ, 2011. 528 с.

${ }^{40}$ Мостепанюк В.А., Тарасевич О.В., Ейсмонт В.С., Вишневський В.С. Довідник лісовпорядника. Житомир, 2016. 582 с.

${ }^{41}$ Падій М.М. Лісова ентомологія. Київ : Вид-во УСГА, 1993. 350 с.

42 Лесная энтомология : учебник / под ред. Е.Г. Мозолевской. Москва : Издательский центр «Академия», 2010. 416 с.

${ }^{43}$ Васильев И.В. О насекомых, вредивших сосне в Харьковской губернии в 1900 г. Труды Русского Энтомол. об-ва. 1902. Т. 35. С. 13-15.

${ }^{44}$ Иерусалимов Е.Н. О содержании крахмала и жиров у поврежденных сосновым шелкопрядом деревьев сосны обыкновенной. Вопросы защиты леса. Москва, 1974. С. 181-186.

${ }^{45}$ Іллінський A.I. Прядка соснова (Dendrolimus pini L.) іï життя й заходи боротьби з нею в лісах. Київ, 1928.40 с.

46 Дрозда В.Ф., Карпович М.С., Гойчук В.Ф. Спосіб захисту хвойних лісів від лускокрилих фітофагів. Патент України № 125014. Опубл. 25.04.2018. Бюл. № 8.

47 Дмитриев Г.В. Основы защиты зеленых насажденый от вредных членистоногих. Киев : Урожай, 1969. $410 \mathrm{c}$.

${ }^{48}$ Marini, M. Dendrolimus-Pini-Calabrica New-Subspecies from Southern Italy Lepidoptera Lasiocampidae. Bollettino della Societa Entomologica Italiana. 1986. № 118 (1-3). P. $20-24$.

${ }^{49}$ Kirichenko, N.I., Baranchikov, Y.N., Vidal, S. Performance of the potentially invasive Siberian moth Dendrolimus superans sibiricus on coniferous species in Europe. Agricultural and Forest Entomology. 2009. № 11 (3). P. 247-254

${ }^{50}$ Kolk, A., Starzyk J.R. Pine moth (Dendrolimus pini L.), Atlas skodliwych owadów lesnych (The atlas of forest insect pests). Multico Warszawa, 1996. $705 \mathrm{p}$.

51 Загайкевич І.К. Комахи - шкідники деревних і чагарникових порід західних областей України. Київ : Видавничої академії України РСР, 1958. 132 с.

${ }^{52}$ Borowski, J. Observations on the bionomy of selected harmful insects feeding on foreign coniferous species. Sylwan. 2005. № 149 (6). P. 17-20.
} 
(Abietoideae) ялицею білою Abies $a l b a^{53} ; 3$ підродини Кипарисові (Cupressaceae) ялівцем звичайним (Juniperus communis L.) ${ }^{54}$.

Масовий літ метеликів спостерігається у червні - липні, триває 3040 днів (рис. 1). За нашими спостереженнями виражена льотна активність імаго спостерігається ввечері та вночі, при цьому імаго долає значні відстані ${ }^{55}$. Вдень імаго сидить нерухомо на стовбурах і гілках дерев. Спаровування продовжується до 10 годин ${ }^{56}$. Розмноження двостатеве ${ }^{57}$.

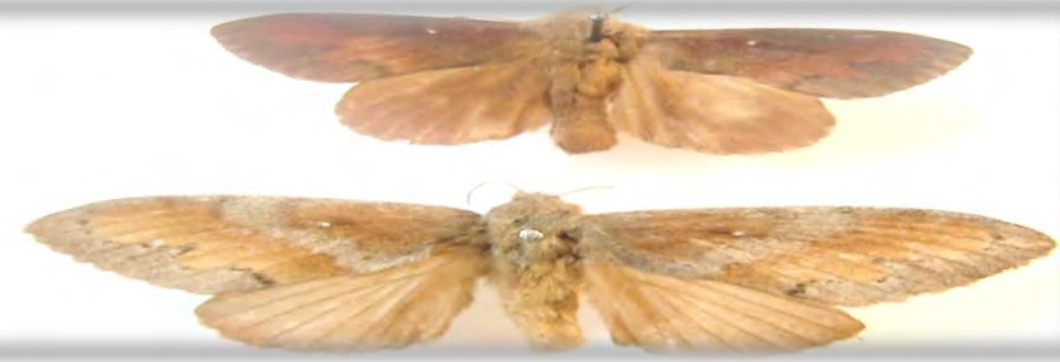

Рис. 1. Імаго соснового шовкопряда (фото авторів)

Через 7-10 днів після спаровування самиці відкладають яйця, цей процес триває 3-5 діб, після чого самиця гине ${ }^{58}$. Самиці відкладають яйця групами, зазвичай по 50-60 штук і в стиглому, і перестиглому лісі на кору стовбурів сосни, в молодняках - переважно на хвою і гілки, рідше на стовбурах на висоті до 2-3 м від землі ${ }^{59}$ (рис. 2).

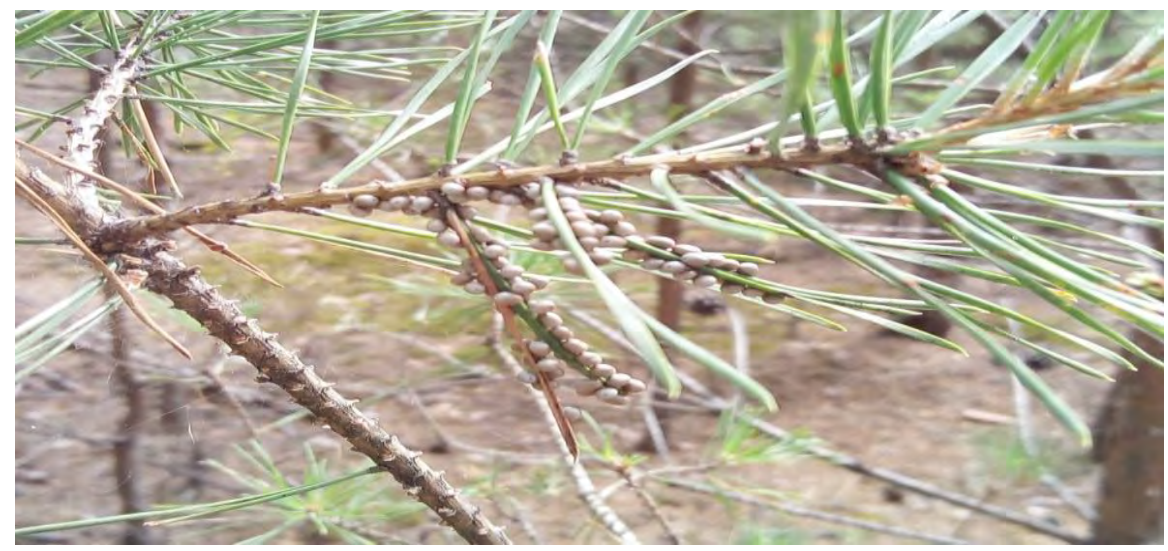

Рис. 2. Групове відкладання яєць (фото авторів)

\footnotetext{
53 Baldassari, N. Cedrus deodara, a new host plant for Dendrolimus pini, Pandemis cerasana and Argyrotaenia ljungiana. Monti e Boschi. 1996. № 47 (1). P. 39.

4 Davis, E., Albrecht, E.M., Venette, R.C. Dendrolimus pini. In: Exotic pine pests: survey reference.Cooperative agriculture pest survey (ed.: R.C. Venette). Northern Research Station, USDA ForestService, St. Paul, MN, USA, 2008. P. 122-130.

${ }_{55}$ Аверкиев И.С. Атлас вреднейших насекомых леса. Москва : Лесн. пром.-сть, 1984. 72 с.

${ }^{56}$ Гамаюнова С.Г., Новак Л.В., Войтенко Ю.В., Харченко А.Е. Массовые и хвое- и листогрызущие вредители леса. Харьков : УНИНЛХиА им. Г.Н. Высоцкого, 1999. 172 с.

Сосновий шовкопряд Dendrolimus pini. URL: https://www.biochemtech.com.ua/sosnoviyshovkopryad-dendrolimus-pini/ (дата звернення: 25.06.2020).

${ }_{59}^{58}$ Анфінніков М.О., Лісовський А.В. Хвороби дерев, күщів, чагарників. Лебедин, 2010. 63 с.

59 Теленга Н.А. Биологический метод борьбы с вредными насекомыми сельскохозяйственных и лесных культур. Киев : Академия наук Украинской ССР, 1955. 144 с.
} 
У кожній кладці від 10 до 200 яєць. Плодючість самиць соснового шовкопряда коливається в межах від 50 до 450 яєць ${ }^{60}$. Яйця (рис. 3) спочатку світло-зелені, надалі - сірі, з одного боку мають чорну цятку. Тривалість ембріонального розвитку складає 16-20 діб за температури від $+16^{\circ} \mathrm{C}$ до $18^{\circ} \mathrm{C}$.

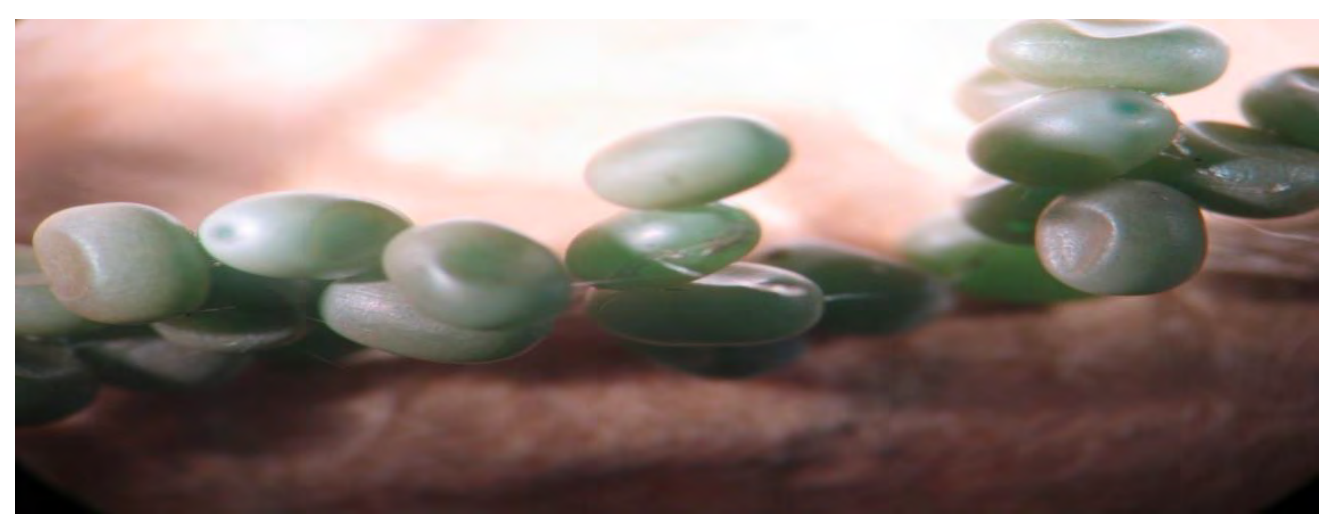

Рис. 3. Яйця соснового шовкопряда (фото авторів)

Відродження гусениць відбувається на початку серпня. Гусениці живляться хвою поточного року, обгризаючи ії з боків по всій довжині. Забарвлення гусениць залежить від кольору сосни звичайної - від сірого до бурувато-сірого. Гусениці характеризуються вираженою руховою та трофічною активністю.

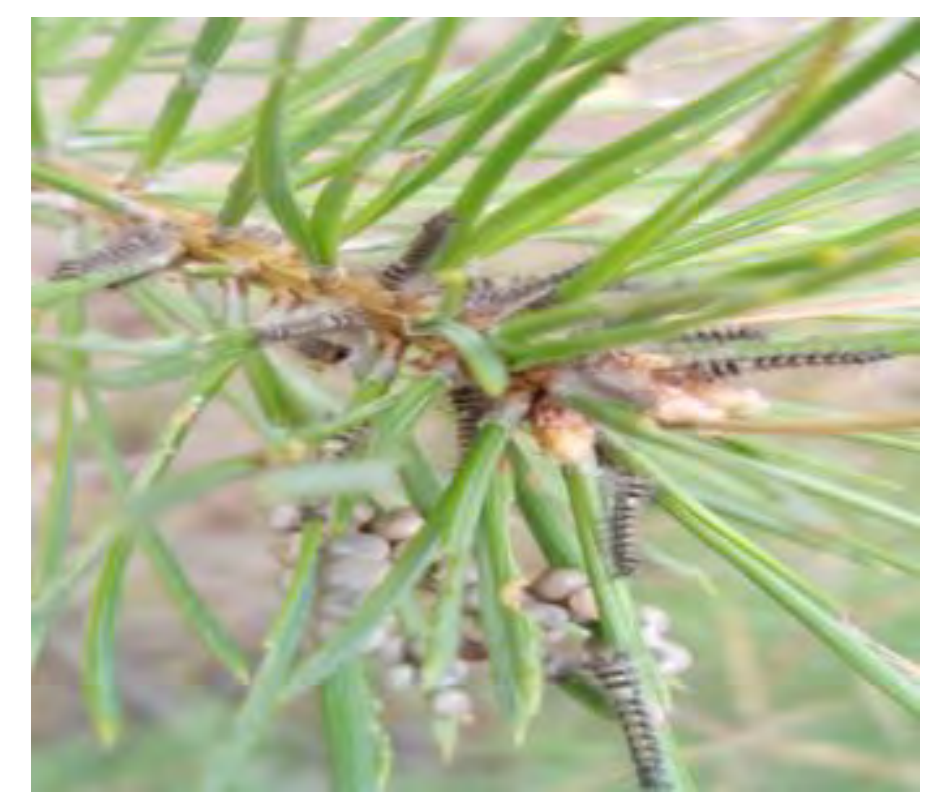

\section{Рис. 4. Відроджені гусениці (фото авторів)}

\footnotetext{
${ }^{60}$ Тимченко Г.А., Авраменко И.Д., Завада Н.М. Справочник по защите леса от вредителей и болезней. Киев : Урожай 1988. 222 с. 
Зимують гусениці III-IV віків у листковому опаді, моховому покриві, на поверхні грунту й у грунті на незначній глибині до 7 см у лісовій підстилці.

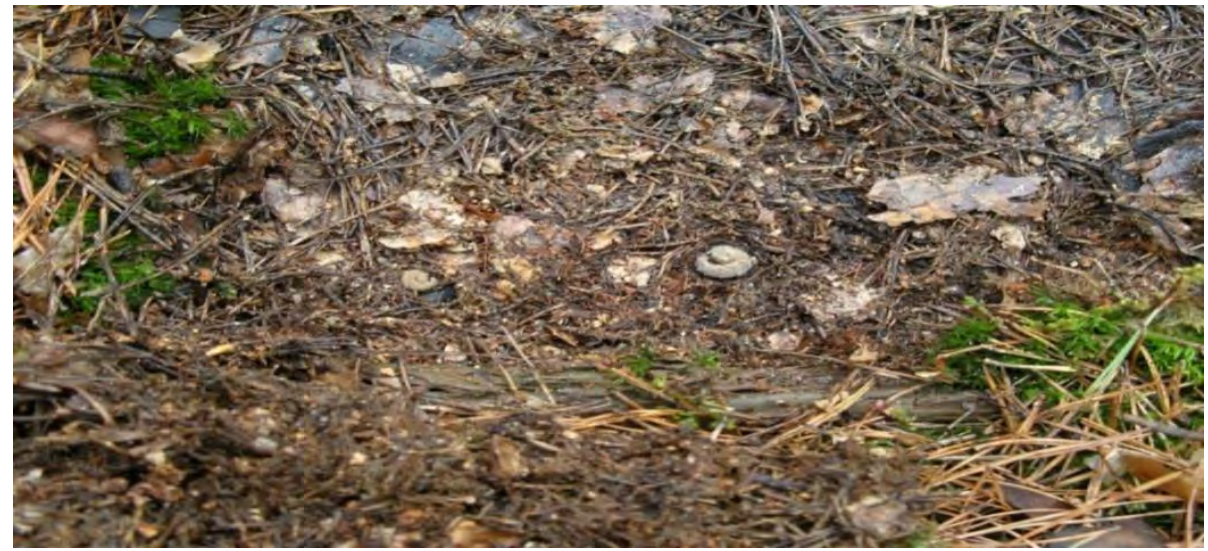

\section{Рис. 5. Гусінь соснового шовкопряда у підстилці(фото авторів)}

За нашими дослідженнями встановлено характер формування діапаузуючих популяцій соснового шовкопряда. Фізіологічно повноцінні гусениці концентруються на поверхні грунту й у грунті. Ослаблені популяції концентруються в листковому опаді. Переважно від 56,5 до $85 \%$ гинуть у період весняної реактивації.

Навесні за температури $10^{\circ} \mathrm{C}$ із місця залягання гусениці переповзають по стовбурах у крону (рис. 6) і починають живитися молодою хвоєю, пошкоджують також травневі пагони та бруньки ${ }^{61}$.

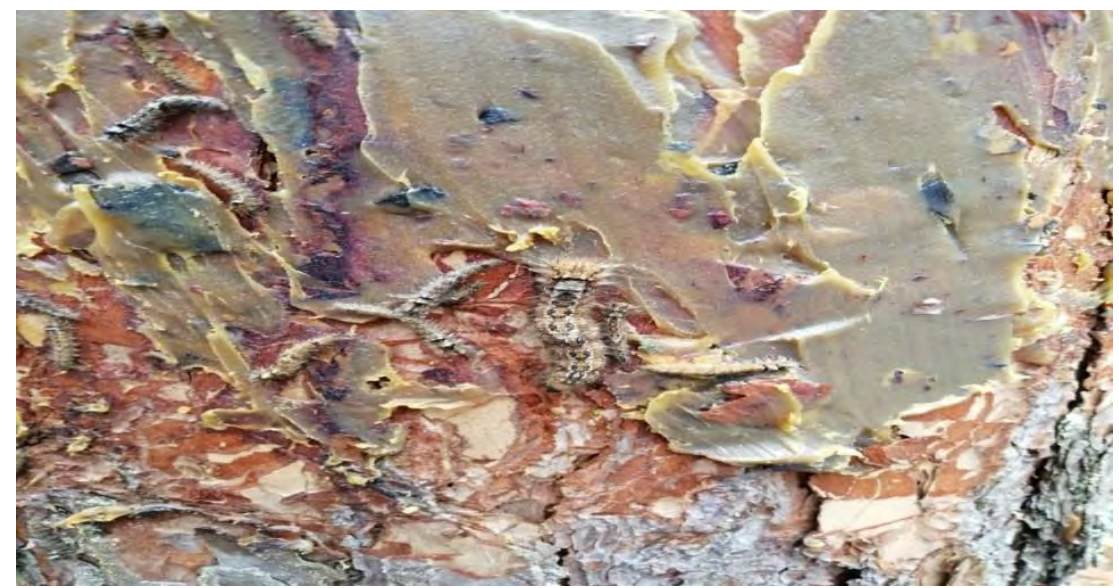

Рис. 6. Гусінь навесні піднімається у крону дерев(фото авторів)

Живляться гусениці до кінця червня, потім заляльковуються (рис. 7) у тріщинах кори, на гілках.

\footnotetext{
${ }^{61}$ Карпович М.С., Дрозда В.Ф. Особливості біології, екології соснового шовкопряда (Dendrolimus pini Linnaeus, 1758) у соснових насадженнях Полісся. Таврійський вісник. 2020. № 112. С. $265-275$.
} 


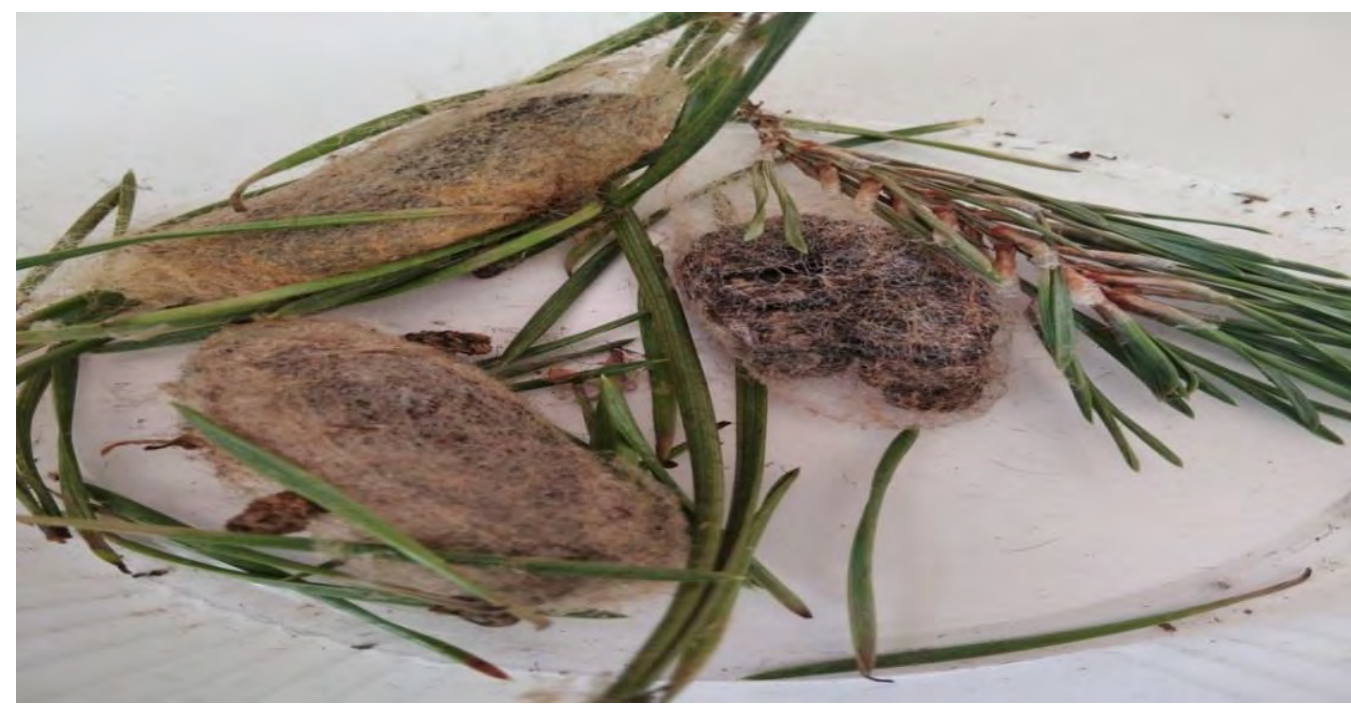

\section{Рис. 7. Залялькування гусениць соснового шовкопряда (фото авторів)}

\section{2. Біологічні й екологічні особливості трихограми (Trichogramma evanescens Westw.)}

Трихограма належить до родини трихограматид (Trichogrammatidae), надродини хальцид (Chalcidae), ряду перетинчастокрилих (Hymenoptera) ${ }^{62}$. Види роду (Trichogramma)представлені виключно паразитами яєць. У комплексні 3 іншими ентомофагами вони контролюють чисельність багатьох фітофагів сільського та лісового господарства ${ }^{63,64,65}$. У практиці біометоду трихограму використовують проти шкідливих лускокрилих шляхом масового розведення і випуску в природу ${ }^{66}$.

У світовій практиці біологічного методу захисту рослин використовуються 15 видів роду Trichogramma на 22 видах сільськогосподарських культур і дерев, у т. ч. на промислових культурах, овочах, фруктових насадженнях, хвойних та листяних деревах (сосна, ялина) ${ }^{67}$.

\footnotetext{
${ }^{62}$ Федоренко В.П., Конверська В.П., Колісніченко В.С., Сядриста О.Б. Технологія використання видів роду трихограма (Hymoptera, Trichogrammatidae) в регулюванні чисельності лускокрилих шкідників овочевих культур : методичні рекомендації. Київ : Інститут захисту рослин УААН, 2004. $50 \mathrm{c}$.

${ }^{63}$ Фурсов В.Н., Сторожева Н.А. Выявление, определение и районирование хозяйственно важных видов яйцеедов рода Trichogramma Westw. в агробиоценозах Украины: Препринт. АН УССР / Ин-т зоологии. 1990. № 26. С. 1-47.

${ }^{64}$ Smith S.M. Methods and timing releases of Trichogramma to control lepidopterous pests. Annu. Rev. Entomol. 1994. № 32. P. 113-144.

${ }^{65}$ Vieira A., Oliveira L., Garcia P. Effects of conventional pesticides on the preimaginal developmental stages and on adults of Trichogramma cordubensis (Hym.: Trichogrammatidae). Biocon T. Science and Technol. 2001. № 4. P. 527-534.

${ }^{66}$ Сорокина А.П. Определитель видов рода Trichogramma Westw. (Hymoptera, Trichogrammatidae) мировой фауны. Москва : Колос, 1993. 75 с.

${ }^{67}$ Parra J.R.P., Zucchi R.A. Trichogramma in Brazil: feasibility of use after twenty years of research. Neotropical Entomology. 2004. № 33. P. 271-281.
} 
Позитивні властивості трихограми - швидкість розвитку та вигідне співвідношення статей - забезпечують високі темпи розмноження. У природних популяціях буває від 70 до 90\% самиць. Цикл розвитку за оптимальних умов триває 9-14 днів. За вегетаційний період у Поліссі розвивається 5-6 поколінь.

Трихограма здатна до паразитування яєць комах господарів упродовж всього вегетаційного періоду. Значна частина природної популяції трихограми, що відроджується навесні, гине, через відсутність яєць комах-господарів.

Вид теплолюбивий, розповсюджений в Україні скрізь. Характеризується вузьким діапазоном сприятливих температур $\left(19-24^{\circ} \mathrm{C}\right)$ за відносної вологості 60-80\%. Оптимальні умови розвитку: відносна вологість - 75-80\%, температур $21-24^{\circ} \mathrm{C}$. Плодючість самиць 20-24 яйця, максимальна - 50. Зниження вологості зумовлює скорочення виживаності та кількості самок у наступних поколіннях ${ }^{68}$.

Характерною особливістю трихограми $\epsilon$ те, що самиці не відрізняються вираженою руховою активністю, та пошуковою здатністю яєць живителя. Згідно літературних джерел та наших досліджень, встановлено, що самиці після ретельного моніторингу субстрату - хвої сосни знаходять яйця соснового шовкопряда. Після цього проводять їх ретельний Проводять після цього ретельний їх фізіологічний моніторинг, оцінюючи рівень їх життєздатності на придатність личинок паразитами для оптимального розвитку.

Таким чином, згідно літературних i власних досліджень цілком очевидно експериментально обгрунтувати доцільність і ефективність прийомів розселення промислових культур трихограми для контролю чисельності соснового шовкопряда ${ }^{69}$.

\section{3. Біологічні й екологічні особливості теленомуса (Telenomus verticillatus Kieffer)}

Теленомуси порівняно із трихограмами $є$ вузькоспеціалізованими паразитоїдами. Коло живителів у них обмежене, вони надають перевагу одному фітофагу.

Завдяки здатності теленомуса вести активний i цілеспрямований пошук живителя забезпечується висока активність яйцеїда за низької щільності популяції шкідника, що надзвичайно важливо в міжспалахові роки для попередження його масового розмноження. Важливим технологічним прийом $є$ виявлення оптимальних термінів розселення теленомуса в осередки скупчення соснового шовкопряда.

\footnotetext{
${ }^{68}$ Дрозда В.Ф., Білик Л.І., Зубачов С.Р., Зубачов А.Р. Трихограма використання та показники якості. Черкаси, 2013. 70 с.

69 Крушев Л.Т. Биологические методы защиты леса от вредителей. Москва : Изд. Лесная промышленность, 1973. 192 с.
} 
Зимують запліднені самиці, самці гинуть восени. На зимівлю самиці мігрують переважно в підстилку, рослинні рештки, під кору пнів торішніх рубок, у трухляві дупла. Як показали наші дослідження, в однорідних соснових насадженнях теленомус не знаходить проміжних господарів $\mathrm{i}$ мігрує у пошуках оптимальних екологічних та трофічних ніш ${ }^{70}$.

У той же час, у мішаних насадженнях, навіть 3 незначною домішкою листяних порід, паразит має більш сприятливі умови для розвитку. Очевидно, що для подальшого розвитку дочірних поколінь теленомуса, необхідно створювати консортні осередки у вигляді чагарникових листяних порід.

Наші багаторічні дослідження показали, що впродовж квітня - червня теленомус паразитує яйцях лускокрилих фітофагів переважно на осиці, вербі та березі. У цих специфічних екологічних умовах розвиток теленомуса триває $3-4$ тижні за рахунок додаткових господарів ${ }^{70}$. Очевидно, як показано нашими дослідженнями, цілком виправданим $\epsilon$ прийоми підтримання видового різноманіття шляхом штучних насаджень. Технологічні прийоми спрямовані на максимальне накопичення природних популяцій теленомуса до початку яйцекладки самиць соснового шовкопряда ${ }^{72}$.

Плодючість самиць теленомуса становить 50-200 яєць, у середньому відкладається 80-85 яєць. В одному яйці шовкопряда розвивається до 24 особин паразита, у середньому - близько 10-12 особин ${ }^{71}$.

Теленомус, незважаючи на його високу ефективність i значне поширення в осередках шовкопряда, не має статусу лабораторної культури. Основною причиною цього $\epsilon$ те, що для вирощування та підтримання лабораторної культури соснового шовкопряда необхідно докладати значні зусилля. Водночас 3 огляду на значне поширення соснового шовкопряда цілком виправданими $\epsilon$ зусилля, спрямовані на вирощування популяцій теленомуса за лабораторних умов ${ }^{72}$.

\section{2. Методика проведення досліджень і їх результативність}

Польові дослідження проводили впродовж 2016-2020 pp. у соснових насадженнях Полісся. Їм передувала серія лабораторних експериментів, де відпрацьовувались окремі моніторингові прийоми, що пов'язані із особливостями промислового розведення ентомофагів розселення ентомофагів, як якість лабораторних культур паразитів, норми, строки та кратності розселення біоматеріалу. Це дозволило, експериментально

\footnotetext{
70 Крушев Л.Т. Биологические методы защиты леса от вредителей. Москва : Изд. Лесная промышленность, 1973. 192 с.

71 Тузов В.К., Калиниченко Э.М., Рябинов В.А. Методы борьбы с болезнями и вредителями леса. Москва : ВНИИЛМ, 2003. 112 с.

${ }^{72}$ Karpovich M.S., Drozda V.F. Technological features laboratory breeding (Telenomus verticilatus Kieffer, 1917), parasite of the pine (Dendrolimus pini L.). Bulletin of Poltava State Agrarian Academy. 2020. № 2. P. 101. doi: 10.31210/visnyk2020.02.06.
} 
обгрунтувати об'єктивні технологічні прийоми, що стосуються процедури розселення паразита.

Визначальні деталі польових досліджень враховували специфіку та характер функціонування лісостанів так і комах фітофагів.

Враховуючи гетерогенність популяції соснового шовкопряда, детально досліджували інтенсивність заселення дерев залежно від їхнього фізіологічного стану, який оцінювали візуально за характером та інтенсивністю забарвлення хвої та лінійними розмірами.

Моніторингова складова частина технологій передбачала серію досліджень, пов'язану зі збором діапаузуючих гусениць соснового шовкопряда. Гусениці соснового шовкопряда збирали в осередках сосни звичайної в лісовій підстилці, біля дерев у радіусі 1,5 м і на глибині грунту до 10 см. Упродовж вегетаційного періоду збирали зразки рослинних решток із поверхні грунту, гілок і кори дерев заражених діапаузуючими стадіями фітофага.

Під деревами у підстилці закладали площадки розміром 1 х0,5 м i здійснювали спостереження за сосновим шовкопрядом під час зимівлі гусениць. Менша сторона примикала дерева, а більша була направлена по радіусу проекції крони ${ }^{73}$. Навесні, до початку реактивації гусениць соснового шовкопряда та їх міграції на штамби дерев на висоті 20-25 см від поверхні землі накладали клейові пояси шириною 15-17 см (рис. 8). Такий прийом дозволив оцінити загальну кількість гусениць фітофага та потенційну загрозу насадженням. У період живлення гусениць проводили околот дерев. Причому щоразу визначали кількість і віковий склад виявлених особин, їхню життєздатність ${ }^{74}$.

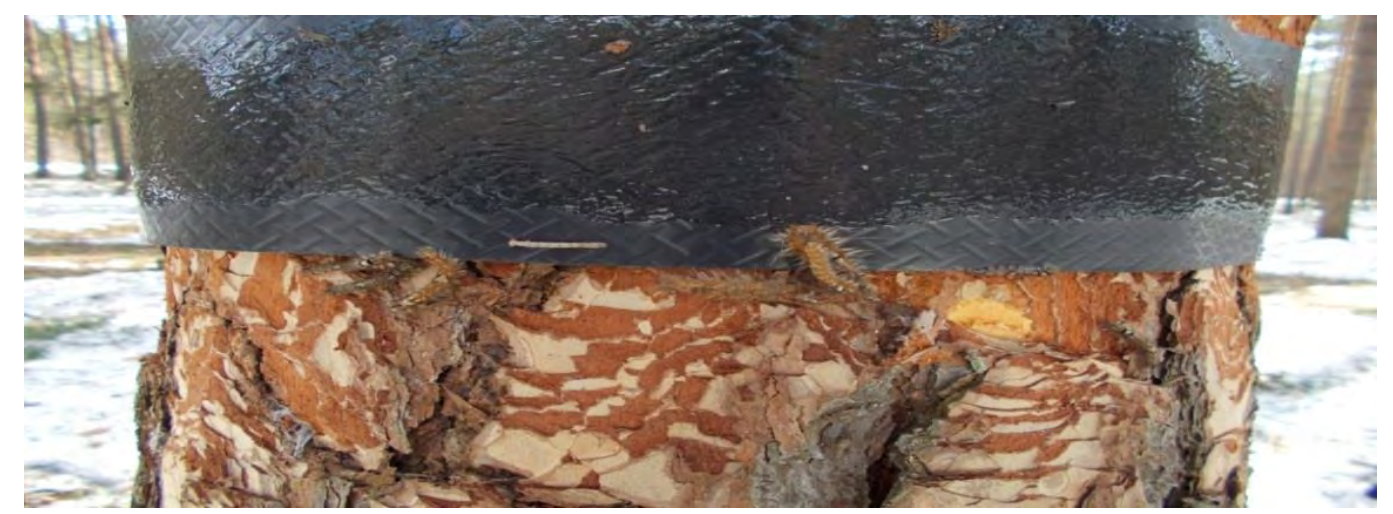

\section{Рис. 8. Міграції гусениць соснового шовкопряда у крони навесні та їхня концентрація у ловильних поясах (фото авторів)}

\footnotetext{
73 Гойчук А.Ф., Решетник Л.Л., Максимчук Н.В. Лісопатологічні обстеження : навчальний посібник / за ред. А.Ф. Гойчук. Житомир : «Полісся», 2012. 136 с.

74 Дрозда В.Ф., Карпович М.С., Гойчук В.Ф. Спосіб пригнічення процесу поширення та трофічної активності популяцій соснового шовкопряда (Dendrolimus pini L.). Патент України № 124581, Опубл. 10.04.2018, Бюл. № 7.
} 
Крім того, важливою складовою досліджень були прийоми фізіологічного моніторингу популяції соснового шовкопряда 3 визначенням їx біотичного потенціалу, рівня та причин загибелі діапаузуючих гусениць. Зокрема, визначали частку гусениць, що загинула внаслідок ураження їх ентомопатогенами, грибної, бактеріальної та протиозойної етеології. Встановлено також рівень ураження їх ентомофагами. Це дозволило отримати об'єктивну інформацію про реальний стан життєздатності фітофага, що дозволило визначити такі характеристики, як норми, та кратність розселення паразитів. При цьому, ставилося завдання не тотального знищення соснового шовкопряда, а тільки суттєве зниження чисельності фітофага до порогового рівня.

Лабораторні дослідження проводили на базі Української лабораторії якості та безпеки продукції АПК. За оптимальних умов розводили та накопичували необхідну кількість біоматеріалу, зокрема промислових культур трихограми (Trichogramma evanescens Westw.) та теленомуса (Telenomus verticillatus Kieff.).

Визначали масу гусениць, їх лінійні розміри, вік і забарвлення. Кожній гусениці присвоювали номер, підписували, де знаходили (підстилка чи грунт) та експонували у природні умови для зимівлі. Весною у садках до періоду їх весняної реактивації повторно проводили такий самий аналіз. Визначали рівень зараження ентомофагами, збудниками хвороб. Визначали рівень життєздатності.

Після відродження гусениць пересаджували на дерева сосни звичайної. Визначали інтенсивність живлення, об'єм спожитої хвої, порогові рівні чисельності та шкідливості, масу гусениць, їхні лінійні розміри, забарвлення перед залялькуванням. Проводили збір лялечок.

Нашими дослідженнями відпрацьована технологія фізіологічного моніторингу соснового шовкопряда, що передбачала оцінку репродуктивного потенціалу самиць. Прижиттєве препарування гонад самиць фітофага показало структуру та характер формування складових частин гонад гермарію, вітеллярію й оваріол. Оогонез самиць, які живилися повноцінним кормом, за оптимальних гідротермічних умов функціонував у циклічному режимі, коли спостерігався певний баланс між ооцитами і трофічними клітинами. Зовсім інша картина спостерігалася за умов харчування гусениць фізіологічно неповноцінним кормом.

Спостерігалася дисфункція розвитку складових частин гонад гермарію та вітеллярію. Як наслідок, окремі оваріоли зазнавали незворотних морфологічних змін, і реальна плодючість самиць знижувалася на 55-70\%. Встановлено також, що різкі перепади температур у період яйцекладки впливали на іiі ритміку, а також і на реальну плодючість 
самиць фітофага. За тривалого похолодання (5-7 днів) значна частина самиць шовкопряда гинула, не відкладаючи яєць ${ }^{76}$.

Важливий прийом моніторингового характеру - використання феромонних пасток із синтетичними статевими феромонами для спостереження за динамікою льоту самців соснового шовкопряда.

Використовували фольгапленовий диспенсер із діючою Z5, E7додекадієн-1-аль; Z5, E7- додекадієн-1-ол. На площі 1 га соснових насаджень експонували не менше 5 пасток ${ }^{75}$, які розташували у середині крони на висоті 1,60 м від поверхні грунту. Упродовж 2-3 днів проводили спостереження 3 підрахунками та вилучення самців соснового шовкопряда, які потрапляли в пастку.

Згідно 3 нашими дослідженнями після відлову 5-7 самців упродовж 7 днів визначали пороговий рівень чисельності фітофага. Таким чином визначали початок і тривалість льоту імаго соснового шовкопряда, а також встановлювали початок і тривалість масового льоту ${ }^{76}$.

На початку яйцекладки самиць шовкопряда, 3 інтервалом 5-7 днів проводили три прийоми розселення на дерева промислової культури трихограми виду (Trichogramma evanescens Westw.) (рис. 10) i3 розрахунку 5; 10 та 5000 тисяч особин на 1 дерево. Трихограму наклеювали за допомогою цукрового сиропу на паперові карти, які експонували в середню частину крони дерев iз 4 сторін. Це припадало на початок, середину та кінець масового льоту імаго.

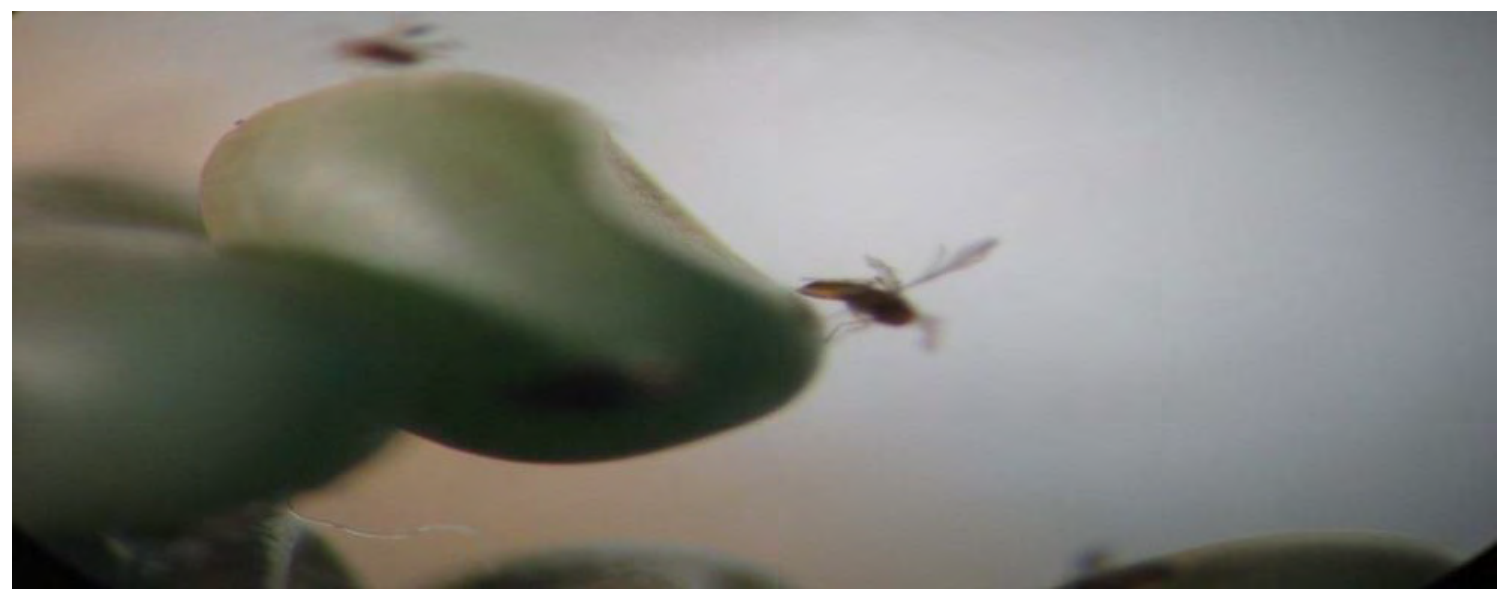

Рис. 9. Зараження ясць соснового шовкопряда трихограмою (фото авторів)

\footnotetext{
75 Дрозда В.Ф., Карпович М.С., Гойчук В.Ф. Спосіб контролю чисельності та шкідливості соснового шовкопряда (Dendrolimus pini L.) в насадженнях сосни звичайної (Pinus sylvesris L.). Патент України № 124580 опубліковано 10.04.2018. Бюл. № 7.

${ }^{76}$ Карпович М.С., Дрозда В.Ф. Технологічні особливості біологічного захисту соснових насаджень від соснового шовкопряда (Dendrolimus pini L.) в лісах Черкащини. Вісник Харківського національного аграрного університету ім. В.В. Докучаєва. Серія : Фітопатологія та ентомологія. 2019. № 1-2. C. 56-64.
} 
Крім того, на початку періоду масової яйцекладки фітофагів проводили три прийоми розселення на дерева паразита яєць фітофага теленомуса (Telenomus verticillatus Kieff.) (рис. 9) у перший і третій прийоми, а також розселення трихограми - другий прийом, інтервал між розселенням ентомофагів становив 8-9 днів, за норм розселення теленомуса 220-230 особин на 1 дерево. Для розселення використовували тільки високожиттєздатні лабораторні культури ентомофагів першого класу якості.

Оскільки обидва ентомофаги паразитують на яйцях соснового шовкопряда, їхнє сумісне розселення супроводжувалося міжвидовою конкуренцією, що сприяло підвищенню рівня паразитування. Було передбачено 5 варіантів і контроль.

Оригінальна авторська технологія передбачала сумісне розселення трихограми та теленомуса у системі навколишнього ландшафту. Ландшафт - природні хвойні, дерев'янисті та чагарникові насадження, частково штучно сконструйовані шляхом підсіву трав'янистих нектароносних рослин. Їх висівали з інтервалом 10 днів у 4 строки, що забезпечило їх цвітіння упродовж вегетаційного періоду. Це специфічна екологічна ніша, де накопичувалися, розмножувалися, живилися нектаром i пилком природні популяції ентомофагів із подальшим розселенням у лісостани. Інші варіанти - оцінка окремого розселення трихограми та теленомуса. Передбачалися варіанти механічного знищення гусениць, котрі після перезимівлі мігрували і заселяли дерева та хімічний еталон. Оцінку технологій проводили 3 використанням найбільш об'єктивних та інформативних тестових показників. Отриманий цифровий матеріал обробляли статистично. Результати досліджень наведені у табл. 1.

На фоні значної стартової чисельності яєць соснового шовкопряда отримано цілком об'єктивні результати, що дозволило не тільки оцінити ефективність прийомів, але і зробити висновок про доцільність використання цих прийомів на практиці. Оцінивши оригінальну технологію, необхідно відзначити, що підсумкова іiі ефективність становила 92,7\%. Це високий і цілком сприятливий для практики результат. Наголошуємо на тому, що використовували ентомофаги першого класу якості - високо життєздатні лабораторні культури. Загальна ефективність цієї технології складалася не тільки як результат реалізації та приваблювання природних популяцій ентомофагів. Як видно, прийоми окремого використання обох ентомофагів теж дають позитивний результат, проте їхня господарська ефективність $\epsilon$ недостатньою. 
Біологічна та господарська ефективність реалізації прийомів розселення ентомофагів для захисту сосни від соснового шовкопряда (Українське Полісся, Житомирська область 2016-2020 рр.)

\begin{tabular}{|c|c|c|c|c|c|c|c|}
\hline \multirow[b]{2}{*}{ Технологія захисту } & \multirow{2}{*}{ 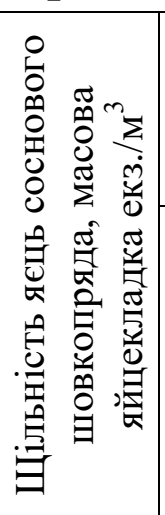 } & \multicolumn{3}{|c|}{$\begin{array}{c}\text { Характер яйцекладки } \\
\text { самиць соснового } \\
\text { шовкопряда у кроні } \\
\text { дерев, \% }\end{array}$} & \multicolumn{2}{|c|}{$\begin{array}{c}\text { Заражено } \\
\text { ентомофагами, } \\
\text { \% }\end{array}$} & \multirow{2}{*}{ 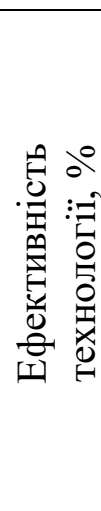 } \\
\hline & & 苗苍 & 焉 & 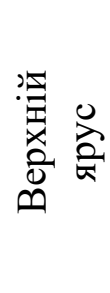 & 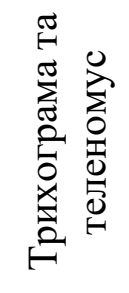 & 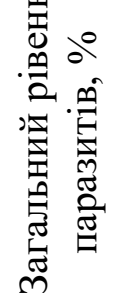 & \\
\hline $\begin{array}{l}\text { Організаційна технологія } \\
\text { захисту, у складі } \\
\text { ландшафту; } 3 \text { прийоми } \\
\text { розселення трихограми } \\
\text { та } 2 \text { прийоми теленомуса }\end{array}$ & 16,4 & 19,2 & 67,1 & 13,7 & 77,5 & 9,4 & 2,7 \\
\hline $\begin{array}{l}\text { Розселення трихограми - } \\
3 \text { прийоми }\end{array}$ & 19,1 & 21,3 & 59,8 & 8,9 & 54,2 & 57,8 & 9,3 \\
\hline $\begin{array}{l}\text { Розселення трихограми - } \\
2 \text { прийоми }\end{array}$ & 15,6 & 16,8 & 68,3 & 1,7 & 48,4 & 52,9 & 5,4 \\
\hline $\begin{array}{l}\text { Накладання клейових } \\
\text { поясів на штамби дерев. } \\
\text { Прийоми механічного } \\
\text { захисту }\end{array}$ & 21,4 & 24,1 & 63,9 & 12,0 & 12,4 & 17,3 & 2,4 \\
\hline Хімічний еталон & 17,5 & 23,5 & 55,9 & 0,6 & 5,7 & 9,3 & 1,7 \\
\hline Контроль & 15,9 & 17,2 & 60,7 & 2,1 & 12,3 & 19,4 & \\
\hline $\mathrm{HiP}_{05}$ & - & - & - & - & 3,7 & 4,1 & 5,2 \\
\hline
\end{tabular}

Необхідно також відзначити, що в Україні функціонує понад 60 біолабораторій, де розводять трихограму, і проблеми з ії отримання для захисту не тільки агроценозів, а і лісостанів не існує.

Технологія розведення теленомуса відпрацьована нами. Вона складається із прийомів, котрі дозволяють підтримувати культуру упродовж цілого року без використання штучних живильних середовищ. Гусениці соснового шовкопряда - господар теленомус - споживають як свіжу, так і торішню хвою, а це значно спрощує технологію розведення соснового шовкопряда.

Таким чином, фактично вперше запропоновано технологію біологічного захисту соснових насаджень від такого небезпечного фітофага, як сосновий шовкопряд. Враховуючи значні площі соснових лісів, зокрема на Поліссі України, та цілковиту недоцільність 3 
екологічних та економічних міркувань використання хімічних препаратів у лісостанах, очевидна перспектива біологічного захисту насаджень сосни звичайної.

\section{ВИСНОВКИ}

У зв'язку з подальшим погіршенням екології запропоновані технології біологічного методу боротьби зі шкідниками лісу, які сприяють зменшенню застосування хімічних методів, що завдають значної шкоди навколишньому середовищу.

Вперше запропонована технологія масового лабораторного розведення трихограми та теленомуса для потреб лісового господарства від соснового шовкопряда.

Експериментально обгрунтовано доцільність сумісного розселення лабораторних культур ентомофагів у соснові насадження для підвищення рівня паразитування.

Грунтуючись на аналізі першоджерел і власних лабораторних та польових досліджень, ми експериментально обгрунтували прийоми, пов'язані з оцінкою та доцільністю розселення лабораторних культур трихограми та теленомуса.

\section{АНОТАЦІЯ}

Складова частина експериментів - моніторингові дослідження, візуальний, інструментальний i фізіологічний моніторинг популяцій соснового шовкопряда, прийоми розведення та розселення теленомуса на дерева лабораторних культур трихограми та теленомуса. Обгрунтовано строки, норми та кратності розселення паразитів.

Вперше запропонована технологія масового лабораторного розведення трихограми та теленомуса для потреб лісового господарства від соснового шовкопряда.

Експериментально обгрунтовано доцільність сумісного розселення лабораторних культур ентомофагів у соснові насадження для підвищення рівня паразитування.

Грунтуючись на аналізі першоджерел і власних лабораторних та польових досліджень, ми експериментально обгрунтували прийоми, пов'язані з оцінкою та доцільністю розселення лабораторних культур трихограми та теленомуса.

\section{ЛІТЕРАТУРА}

1. Аверкиев И.С. Атлас вреднейших насекомых леса. Москва : Лесн. пром.-сть, 1984. 72 с.

2. Анфінніков М.О., Лісовський А.В. Хвороби дерев, кущів, чагарників. Лебедин, 2010. 63 с. 
3. Бунтова О.Г., Бідна С.М., Зленко М.Г., Кучма М.Д., Тютюнник Ю.Г. Чорнобильські ліси: минуле, сучасне, майбутнє. URL: https://inis.iaea.org/ collection/NCLCollectionStore/_Public/32/020/32020526.pdf (дата звернення: 12.01.2020).

4. Васильев И.В. О насекомых, вредивших сосне в Харьковской губернии в 1900 г. Труды Русского Энтомол. об-ва. 1902. Т. 35. С. 13-15.

5. Гамаюнова С.Г., Новак Л.В., Войтенко Ю.В., Харченко А.Е. Массовые и хвое- и листогрызущие вредители леса. Харьков : УНИНЛХиА им. Г.Н. Высоцкого, 1999. 172 с.

6. Гойчук А.Ф., Решетник Л.Л., Максимчук Н.В. Лісопатологічні обстеження : навчальний посібник / за ред. А.Ф. Гойчук. Житомир : «Полісся», 2012. $136 \mathrm{c}$.

7. Гордієнко М.I., Корецький Г.С., Маурер В.М. Лісові культури. Київ : Сільгоспосвіта, 1995. 328 с.

8. Дмитриев Г.В. Основы защиты зеленых насажденый от вредных членистоногих. Киев : Урожай, 1969. 410 с.

9. Дрозда В.Ф., Білик Л.І., Зубачов С.Р., Зубачов А.Р. Трихограма використання та показники якості. Черкаси, 2013. 70 с.

10. Дрозда В.Ф., Карпович М.С. Екологічні особливості соснового шовкопряда (Dendrolimus pini L.), його поширення на Черкащині. Лісівництво і агролісомеліорачія. Вип. 126. 2015. С. 225-231.

11. Дрозда В.Ф., Карпович М.С., Гойчук В.Ф. Спосіб захисту хвойних лісів від лускокрилих фітофагів. Патент України № 125014. Опубл. 25.04.2018. Бюл. № 8.

12. Дрозда В.Ф., Карпович М.С., Гойчук В.Ф. Спосіб пригнічення процесу поширення та трофічної активності популяцій соснового шовкопряда (Dendrolimus pini L.). Патент України № 124581, Опубл. 10.04.2018, Бюл. № 7 .

13. Дрозда В.Ф., Карпович М.С., Гойчук В.Ф. Спосіб контролю чисельності та шкідливості соснового шовкопряда (Dendrolimus pini L.) в насадженнях сосни звичайної (Pinus sylvesris L.). Патент України № 124580 опубліковано 10.04.2018. Бюл. № 7.

14. Загайкевич І.К. Комахи - шкідники деревних і чагарникових порід західних областей України. Київ : Видавничої академії України РСР, 1958. $132 \mathrm{c}$.

15. Иерусалимов Е.Н. О содержании крахмала и жиров у поврежденных сосновым шелкопрядом деревьев сосны обыкновенной. Вопросы зашиты леса. Москва, 1974. С. 181-186.

16. Надзор, учет и прогноз массовых размножений хвое- и листогрызущих насекомых в лесах СССР / ред. А.И. Ильинский, И.В. Тропин. Москва : Лесн. Пром-сть, 1965. 525 с. 
17. Іллінський A.I. Прядка соснова (Dendrolimus pini L.) ï життя й заходи боротьби з нею в лісах. Київ, 1928.40 с.

18. Карпович М.С., Дрозда В.Ф. Роль ентомофагів у популяції соснового шовкопряда (Dendrolimus pini L.) в соснових насадженнях Черкащини. Вісник ХНАУ. Серія «Фітопатологія і ентомологія». 2018. № 1-2. С. 57-62.

19. Карпович М.С., Дрозда В.Ф. Технологічні особливості біологічного захисту соснових насаджень від соснового шовкопряда (Dendrolimus pini L.) в лісах Черкащини. Вісник Харківського національного аграрного університету ім. В.В. Докучаєва. Серія : Фітопатологія та ентомологія. 2019. № 1-2. С. 56-64.

20. Карпович М.С., Дрозда В.Ф. Особливості біології, екології соснового шовкопряда (Dendrolimus pini Linnaeus, 1758) у соснових насадженнях Полісся. Таврійський вісник. 2020. № 112. С. 265-275. URL: https://doi.org/10.32851/2226-0099.2020.111.36.

21. Карпович М.С., Дрозда В.Ф. Поширення соснового шовкопряда (Dendrolimus pini L.) в соснових насадженнях України. Збірник наукових матеріалів XLVIII міжнародної науково-практичної інтернетконференеиї el-conf.com.иа. м. Тернопіль. 2020. С. 64-68.

22. Краснов В.П., Ткачук В.І., Орлов В.В. Довідник із захисту лісу. Київ : Еко-інформ, 2011. 528 с.

23. Крушев Л.Т. Биологические методы защиты леса от вредителей. Москва : Изд. Лесная промышленность, 1973.

24. Кукіна О.М. Комахи-хвоєгризи Чигиринського бору. Лісівництвво $i$ агролісомеліораиія. 2014. Вип. 124. С. 177-184.

25. Мєшкова В.Л. Історія і географія масових розмножень комаххвоєлистогризів. Харків : Майдан, 2002. 244 с.

26. Лесная энтомология : учебник / под ред. Е.Г. Мозолевской. Москва : Издательский центр «Академия», 2010. 416 с.

27. Мостепанюк В.А., Тарасевич О.В., Ейсмонт В.С., Вишневський В.С. Довідник лісовпорядника. Житомир, 2016. 582 с.

28. Падій М.М. Лісова ентомологія. Київ : Вид-во УСГА, 1993. 350 с.

29. Перевізник А.В. Обліки популяцій соснового шовкопряда (Dendrolimus pini L.). Науковий пошук молоді для сталого розвитку лісового комплексу та садово-паркового господарства : тези доповідей учасників 73-ої всеукраїнської студентської науково-практичної конференції, 21 березня 2019 р. Київ : НУБІП, 2019. С. 79-80.

30. Перевізник А.В. Аналіз поширення соснового шовкопряда Dendrolimus pini L. в ДП «Чигиринське л/г». Лісова типологія як основа наближеного до природи лісівництва : тези доповідей учасників міжнародної науково-практичної конференції, 9-12 жовтня 2019 р. Київ : НУБІП, 2019. С. 125-126. 
31. Сорокина А.П. Определитель видов рода Trichogramma Westw. (Hymoptera, Trichogrammatidae) мировой фауны. Москва : Колос, 1993. 75 с.

32. Теленга Н.А. Биологический метод борьбы с вредными насекомыми сельскохозяйственных и лесных культур. Киев : Академия наук Украинской ССР, 1955. 144 с.

33. Тимченко Г.А., Авраменко И.Д., Завада Н.М. Справочник по защите леса от вредителей и болезней. Киев : Урожай 1988. 222 с.

34. Тузов В.К., Калиниченко Э.М., Рябинов В.А. Методы борьбы с болезнями и вредителями леса. Москва : ВНИИЛМ, 2003. $112 \mathrm{c.}$

35. Федоренко В.П., Конверська В.П., Колісніченко В.С., Сядриста О.Б. Технологія використання видів роду трихограма (Hymoptera, Trichogrammatidae) в регулюванні чисельності лускокрилих шкідників овочевих культур : методичні рекомендації. Київ : Інститут захисту рослин УААН, 2004. $50 \mathrm{c}$.

36. Фурсов В.Н., Сторожева Н.А. Выявление, определение и районирование хозяйственно важных видов яйцеедов рода Trichogramma Westw. в агробиоценозах Украины: Препринт. АН УССР / Ин-т зоологии. 1990. № 26. С. 1-47.

37. Чудак В. Інформація про стан лісів Полісся та Поділля України. URL: $\quad \mathrm{http}: / / \mathrm{dklg} . \mathrm{kmu}$. gov.ua/forest/control/uk/publish/article;jsessionid= 0496D5C46F8CDF9F264E0C1FC35FC96B.app2?art_id=118307\&cat_id=81 209 (дата звернення: 7.12.2017).

38. Baldassari, N. Cedrus deodara, a new host plant for Dendrolimus pini, Pandemis cerasana and Argyrotaenia ljungiana. Monti e Boschi. 1996. № 47 (1). P. 39.

39. Björkman C., Lindelöw A., Eklund K., Kyrk S., Klapwijk M.J., Fedderwitz F. Nordlander G. A rare event - an isolated outbreak of the pinetree lappet moth (Dendrolimus pini) in the Stockholm archipelago. Entomol Tidskr. 2013. № 134 (1-2). P. 1-9. Uppsala, Sweden.

40. Borowski, J. Observations on the bionomy of selected harmful insects feeding on foreign coniferous species. Sylwan. 2005. № 149 (6). P. 17-20.

41. CAB. 2005. Crop Protection Compendium. CAB International. URL: http://www.cabicompendium.org/cpc. Accessed 18 October 2006.

42. Davis, E., Albrecht, E.M., Venette, R.C. Dendrolimus pini. In: Exotic pine pests: survey reference.Cooperative agriculture pest survey (ed.: R.C. Venette). Northern Research Station, USDA ForestService, St. Paul, MN, USA, 2008. P. 122-130

43. Diaz, J.H. The evolving global epidemiology, syndromic classification, management, and prevention of caterpillar envenoming. American Journal of Tropical Medicine and Hygiene. 2005. № 72. P. 347-357.

44. Gäbler, H. Kritische Raupenzahlen des Kiefernspinners. Forstwissenschaftliches Centralblatt. 1949. № 68. P. 254-256. 
45. Gedminas, A., Žiogas, A. The influence of Dendrolimus pini L. outbreak on the surrounding standsand forest litter entomofauna. Acta Biologica Universitatis Daugavpiliensis. 2008. № 8. P. 287-296.

46. Han, Ruidong, He Zhong, Ge Feng. Factors influencing the population dynamics of pine caterpillars. Entomological Knowledge. 2004. № 41 (6). P. 504-511.

47. Hardin, J.A., Suazo, A. Control Procedures. In: New pest response guidelines. Dendrolimus pine moths (eds.: A. Hardin, J.A. Suazo). USDA Animal and Plant Health Inspection Service, US Department of Agriculture, USA, 2012. P. 107-122.

48. Johansson, B.G., Anderbrant, O., Sierpinski A. Multispecies trapping of six pests of Scots pine in Sweden and Poland. Journal of Applied Entomology. 2002. № 126. P. 212-216.

49. Karpovich M.S., Drozda V.F. Technological features laboratory breeding (Telenomus verticilatus Kieffer, 1917), parasite of the pine (Dendrolimus pini L.). Bulletin of Poltava State Agrarian Academy. 2020. № 2. P. 101. doi: 10.31210/visnyk2020.02.06.

50. Kirichenko, N.I., Baranchikov, Y.N., Vidal, S. Performance of the potentially invasive Siberian moth Dendrolimus superans sibiricus on coniferous species in Europe. Agricultural and Forest Entomology. 2009. № 11 (3). P. 247-254

51. Kolk, A., Starzyk J.R. Pine moth (Dendrolimus pini L.), Atlas skodliwych owadów lesnych (The atlas of forest insect pests). Multico Warszawa, 1996. 705 p.

52. Kovalev, B.G., Bolgar T.S., Zubov P.A., Zharkov D.G., Golosova M., Nesterov E.A., Tvaradze M.S. Identification of additional components of the sex pheromone of Dendrolimus pini. Chemistry of Natural Compounds. 1993. № 29. P. 135-136.

53. Le-Cerf, F. Lepidopteres nauveaux du Moyen Atlas [Morocco (Noctuidae Lasiocampidae)]. Bull Mus Nation Hist Nat. 1932. № 4 (5). P. 510-515.

54. Le Mellec, A., Michalzik, B. Impact of a pine lappet (Dendrolimus pini) mass outbreak on $\mathrm{C}$ and $\mathrm{N}$ fluxes to the forest floor and soil microbial properties in a Scots pine forest in Germany. Canadian Journal of Forest Research. 2008. № 38. P. 1829-1841.

55. Leśniak, A. Certain trophic and intrapopulation conditions of the pine moth (Dendrolimus pini L.) outbreaks. Ekologia Polska. 1976. № 24. P. 565-576.

56. Leśniak, A. Forest stand and site conditions of a pine moth (Dendrolimus pini L.) outbreaks. Ekologia Polska. 1976. № 24. P. 549-563.

57. Leśniak, A. Climatic and meteorological conditions of the pine moth (Dendrolimus pini L.) outbreaks. Ekologia Polska. 1976. № 24. P. 515-547. 
58. Malyshev, D.S. Disappearance of mass outbreaks of Dendrolimus pini L. (Lepidoptera, Lasiocampidae). Acta Phytopathologica et Entomologica Hungarica. 1997. № 32 (1-2). P. 217-221.

59. Malyshev, D.S. Duration of the life cycle of the pine moth Dendrolimus pini L. (Lepidoptera: Lasiocampidae). Entomological Review. 1987. № 67. P. 61-66.

60. Marini, M. Dendrolimus-Pini-Calabrica New-Subspecies from Southern Italy Lepidoptera Lasiocampidae. Bollettino della Societa Entomologica Italiana. 1986. № 118 (1-3). P. 20-24.

61. Meshkova, V. Foliage browsing insects risk assessment using forest inventory information. IUFRO Working Party 7.03.10 Proc. Workshop, 2006. P. 100-108.

62. Molet, T. CPHST Pest Datasheet for Dendrolimus pini. USDA-APHISPPQ-CPHST. 2012. URL: http:/download.ceris.purdue.edu/file/3031 (дата звернення: 17.08.2017).

63. Parra J.R.P., Zucchi R.A. Trichogramma in Brazil: feasibility of use after twenty years of research. Neotropical Entomology. 2004. № 33. P. 271-281.

64. Sierpinska, A. Towards an integrated management of Dendrolimus pini L. McManus, M.M., Liebhold, A.M. (Eds.), Population Dynamics, Impacts, and Integrated Management of Forest Defoliating Insects. GTR NE-247, USDA Forest Service Northeastern Forest Experiment Station, 1998. P. 347-348.

65. Sukovata, L., Kolk A., Jaroszynska J., Krajewska U., Purzynska A., Isidorov V. Host-tree preferences of the pine moth (Lepidoptera: Lasiocampidae) and pine beauty moth (Lepidoptera: Noctuidae) larvae in relation to needle quality. M.L. McManus and A.M. Liebhold (eds.), Proceedings Ecology, Survey and Management of Forest Insects. USD A Forest Service, Kraków, Poland, 2002.

66. Szujecki, A. Ecology of forests insects, second ed. Dr W. Junk Publishers and PWN - Polish Scientific Publishers, 1987.

67. Smith S.M. Methods and timing releases of Trichogramma to control lepidopterous pests. Annu. Rev. Entomol. 1994. № 32. P. 113-144.

68. Varley, G.C. Population changes in German forest pests. The Journal of Animal Ecology. 1949. № 18. P. 117-122.

69. Vieira A., Oliveira L., Garcia P. Effects of conventional pesticides on the preimaginal developmental stages and on adults of Trichogramma cordubensis (Hym.: Trichogrammatidae). Biocon T. Science and Technol. 2001. № 4. P. 527-534.

70. Сосновий шовкопряд Dendrolimus pini. URL: https:// www.biochemtech.com.ua/sosnoviy-shovkopryad-dendrolimus-pini/ (дата звернення: 25.06.2020). 
71. Комаха-шкідник нищить насадження сосни на Чигиринщині. URL: https://www.openforest.org.ua/140040/ (дата звернення: 24.06.2020).

72. Шкідники не знають кордонів. URL: https://dymerlg.com.ua/ no_cache/pres-sluzhba/novina/article/shkidniki-ne-znajut-kordoniv.html (дата звернення: 24.06.2020).

73. Сосновий шовкопряд Іванківське л/г. URL: https:// www.facebook.com/ivankivlis/posts/2304275379865048/ (дата звернення: 25.06.2020)

74. На Чигиринщині сосновий шовкопряд нищить насадження лісівники проведуть хімічний обробіток, проте лише на частині площ. URL: https://lis-ck.gov.ua/?p=22086 (дата звернення: 30.06.2020).

75. 75.500 гектарів лісу у Трушівцях обробили від шкідників. URL: https://suspilne.media/35013-500-gektariv-lisu-u-trusivcah-obrobili-vidskidnikiv/ (дата звернення: 25.06.2020).

\section{Information about authors:}

Karpovich M. S.,

Graduate Student at the Department of Integrated Plant Protection and Quarantine

National University of Life and Environmental Sciences of Ukraine

15, Heroiv Oborony str., Kyiv, 03041, Ukraine

Drozda V. F.,

Doctor of Agricultural Sciences, Professor, Head of the Department of Problems Biodiversity, Synergetics and Sustainable Development National University of Life and Environmental Sciences of Ukraine 15, Heroiv Oborony str., Kyiv, 03041, Ukraine 